Jurnal Abdidas Volume 2 Nomor 5 Tahun 2021 Halaman 1212 - 1216

JURNAL ABDIDAS

http://abdidas.org/index.php/abdidas

\title{
Sosialisasi Penggunaan Aplikasi Youtube di SD Negeri 091316 Pematang Raya
}

\author{
Srinatalia Silaen
}

Fakultas Keguruan dan Ilmu Pendidikan, Universitas HKBP Nommensen Pematangsiantar, Indonesia

E-mail : $\underline{\text { srinatalia.silaen92@gmail.com }}$

\begin{abstract}
Abstrak
Pendidikan merupakan salah satu yang terkena dampak dari adanya pandemi Covid-19. Hal tersebut membuat terjadinya perubahan kegiatan belajar mengajar yang semula pembelajaran tatap muka menjadi pembelajaran jarak jauh atau daring. Penerapan daring ini dilakukan mulai dari Sekolah Dasar hingga jenjang perguruan tinggi. Dalam menerapkan pembelajaran ini memerlukan berbagai macam teknologi seperti Handphone atau laptop yang disertai akses internet yang memadai. Berbagai platfrom digunakan untuk dapat melangsungkan kegiatan belajar mengajar seperti Zoom, Whatsapp, Gmeet, Google Classroom, dan Youtube. Pembelajaran ini seharusnya memerlukan peran orang tua, guru, dan siswa untuk bersinergi agar pembelajaran tersebut dapat berjalan dengan maksimal dan efektif. Dalam pembelajaran ini orang tua, guru, maupun peserta didik mampu untuk mengoperasikan teknologi yang digunakan.
\end{abstract}

Kata kunci: media pembelajaran, youtube, Covid-19, sekolah dasar

\begin{abstract}
Education is one of the most affected by the COVID-19 pandemic. This makes teaching and learning activities change which was originally face-to-face learning to distance or online learning. This online application is carried out starting from elementary school to university level. In applying this learning requires various kinds of technology such as cellphones or laptops accompanied by adequate internet access. Various platforms are used to be able to carry out teaching and learning activities such as Zoom, Whatsapp, Gmeet, Google Classroom, and Youtube. This learning should require the role of parents, teachers, and students to work together so that learning can run optimally and effectively. In this learning, parents, teachers, and students are able to operate the technology used.
\end{abstract}

Keywords: learning media, youtube, covid-19, elementary school

DOI : https://doi.org/10.31004/abdidas.v2i5.452 


\section{PENDAHULUAN}

Sistem pembelajaran daring (dalam jaringan) merupakan sistem pembelajaran tanpa tatap muka secara langsung antara guru dan siswa tetapi dilakukan melalui online yang menggunakan jaringan internet. Guru harus memastikan kegiatan belajar mengajar tetap berjalan, meskipun siswa berada di rumah. Solusinya, guru dituntut dapat mendesain media pembelajaran sebagai inovasi dengan memanfaatkan media daring (online) Anugrahana, (2020); (Ameli et al., 2020). Hal ini sesuai dengan Menteri Pendidikan dan Kebudayaan Republik Indonesia terkait Surat Edaran Nomor 4 Tahun 2020 tentang Pelaksanaan Kebijakan Pendidikan dalam Masa Darurat Penyebaran Corona Virus Disease (Covid-19) (Kebudayaan \& Indonesia, 2020).

Sistem pembelajaran dilaksanakan melalui perangkat personal computer (PC) atau laptop yang terhubung dengan koneksi jaringan internet. Guru dapat melakukan pembelajaran bersama diwaktu yang sama menggunakan grup di media sosial seperti WhatsApp (WA), telegram, instagram, aplikasi zoom ataupun media lainnya sebagai media pembelajaran. Dengan demikian, guru dapat memastikan siswa mengikuti pembelajaran dalam waktu yang bersamaan, meskipun di tempat yang berbeda Siahaan et al., (2021); Atsani, (2020).

Semua sektor merasakan dampak Corona Virus Disease. Dunia pendidikan salah satunya, dilihat dari kejadian sekitar yang sedang terjadi, baik siswa maupun orangtua siswa yang tidak memiliki handphone untuk menunjang kegiatan pembelajaran daring ini merasa kebingungan, sehingga pihak sekolah ikut mencari solusi untuk mengantisipasi hal tersebut. Beberapa siswa yang tidak memiliki handphone melakukan pembelajaran secara berkelompok, sehingga mereka melakukan aktivitas pembelajaran pun bersama. Mulai belajar melalui video call yang dihubungkan dengan guru yang bersangkutan, diberi pertanyaan satu persatu, hingga mengapsen melalui Voice Note yang tersedia di WhatsApp (Fauzi, 2020). Materi-materinya pun diberikan dalam bentuk video di upload ke youtube yang berdurasi kurang dari 2 menit. Pembelajaran daring tidak bisa lepas dari jaringan internet. Koneksi jaringan internet menjadi salah satu kendala yang dihadapi siswa yang tempat tinggalnya sulit untuk mengakses internet, apalagi siswa tersebut tempat tinggalnya di daerah pedesaan, terpencil dan tertinggal (Widyastuti, 2021).

Dalam proses pembelajaran daring, penting untuk ditambahkan pesan-pesan edukatif kepada orangtua dan peserta didik, tentang wabah pandemi Corona Virus Disease (Covid-19). Dengan demikian kita dapati pembelajaran yang sama dengan tatap muka tetapi berbasis online. Efeknya sangat bagus, programnya tepat sasaran, dan capaian pembelajarannya tercapai. Penyebaran virus Covid-19 di Indonesia memiliki dampak pada semua lapisan masyarakat, termasuk pendidikan (Dewi, 2020). Beberapa reformasi politik telah dilakukan dalam mengurangi penyebaran virus, salah satunya melalui belajar online Anhusadar, (2020); Windhiyana, (2020).

Tujuan pengabdian kepada masyarakat saat ini untuk penyuluhan informasi kepada masyarakat di daerah Pematang Raya yang memiliki anak usia sekolah dalam pendampingan belajar online. Diharapkan dengan adanya sosialisasi ini anakanak tidak lagi merasa bosan dalam belajar online.

\section{METODE}

Kegiatan pengabdian ini diawali dengan penjelajahan lokasi dan perizinan untuk melaksanakan pengabdian masyarakat di Kawasan Pematang Raya, serta menyepakati waktu pelaksanaan. Sasaran kegiatan ini adalah penduduk disekitar daerah tersebut yang memasuki anak usia 
sekolah tingkat SD. Kegiatan pengabdian ini berlangsung dalam bentuk sosialisasi melalui ceramah dan metode tanya jawab bagi masyarakat yang memiliki anak usia sekolah, serta pembagian masker dan sabun cuci tangan sebagai upaya penerapan protokol kesehatan bagi anak. penyebaran virus Corona.

\section{HASIL DAN PEMBAHASAN}

Kegiatan penyuluhan selama dua hari sejak tanggal 13-14 Januari 2021 bertempat di SD Negeri 091316. Kegiatan dibuka secara resmi oleh Bapak Kepala Sekolah Edward Sinaga. Kegiatan hari pertama berupa sosialisasi tentang tata cara kesehatan dan dilanjutkan dengan workshop dan sosialisasi media pembelajaran daring menuju era tatanan normal baru.

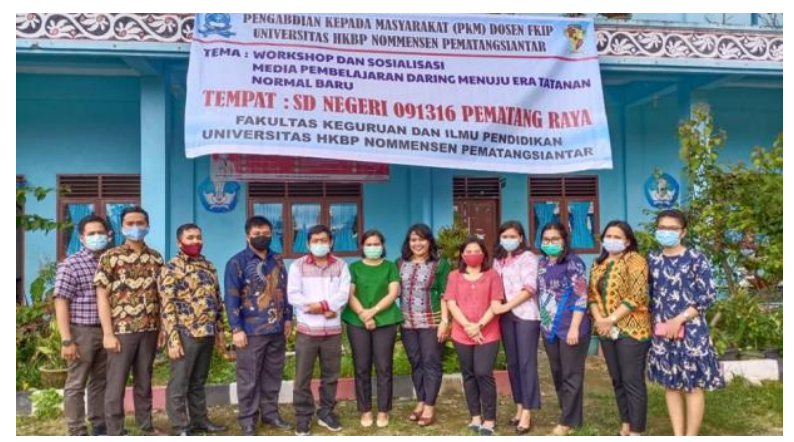

Gambar 1. Kegiatan Pengabdian Masyarakat disambut Bapak Kepala Sekolah SD Negeri 091316

Bukan hanya siswa yang beradaptasi, guru pun beradaptasi dengan perubahan ini. Peran guru berubah, tapi peran secara fisik berkurang karena penggunaan berbagai media pengajaran. Guru juga dipaksa belajar teknologi baru dengan berbagai media pembelajaran. Guru mulai membuat video, aplikasi youtube, Moodle, Google Classroom, dan berbagai aplikasi yang terhubung dengan institusi pendidikannya (Pamungkas \& Sukarman, 2020).

Guru juga beradaptasi untuk melakukan asesmen seberapa banyak materi, nilai, dan value yang akan dijadikan bahan ajar agar anak-anak tetap belajar dalam situasi yang nyaman dan menyenangkan (Sanjaya, 2020). Guru juga akan berusaha agar semua siswa dapat mengerjakan tugas tanpa harus membebani anak-anak dan tetap memperhatikan kondisi tiap-tiap anak. Adaptasi teknologi yang kemudian mendorong anak-anak untuk mudah bermigrasi ke era industri 4.0. Selama ini mungkin anak-anak belum sepenuhnya menyadari bahwa era industri 4.0 membuat efisiensi waktu dan tenaga kerja (Yusri et al., 2020).

Dalam hal ini, anak tidak harus pergi ke sekolah dengan menggunakan moda transportasi, tapi dapat langsung melalui online ketika belajar. Apalagi di tengah pandemi Covid-19, teknologi menjadi penghubung utama dalam proses belajar. Dunia maya yang selama ini sudah dijelajahi anakanak menjadi dunia yang benar-benar hadir sebagai sebuah proses pembelajaran. Pembelajaran tatap muka dengan bantuan teknologi internet.

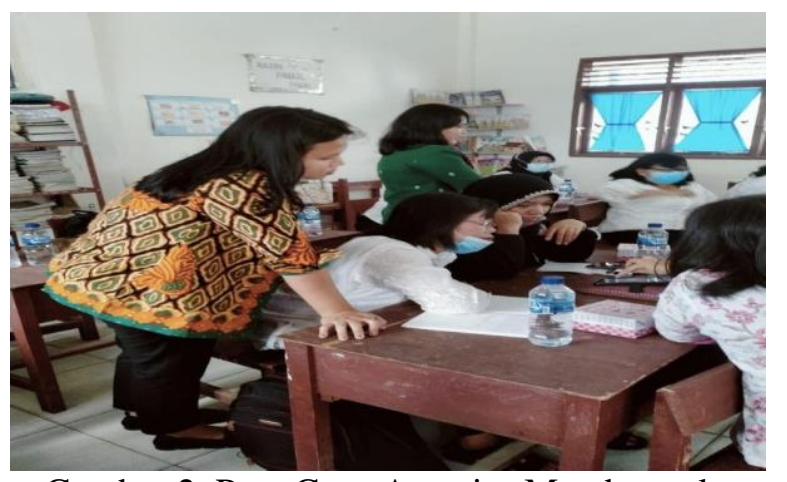

Gambar 2. Para Guru Antusias Mendengarkan Sosialisasi Aplikasi Youtube

Kegiatan belajar sebagaimana mestinya, harus ada komunikasi dua arah antara guru dan wali murid. Membangun pertemuan dengan wali murid sangat dibutuhkan, pengajar memerlukan agar anak bisa belajar dirumah. Kegiatan pengabdian masyarakat yang dilakukan oleh Tim Pengabdian Masyarakat UHKBPNP topik protokol melakukan kesehatan dan pembelajaran online di era normal baru di SD Negeri 091316 sangat diapresiasi oleh masyarakat sekitar. Sebanyak 25 orang dengan anak usia sekolah mendapatkan 
informasi dan wawasan tentang cara membantu anak dengan pembelajaran online. Pembelajaran online dapat menjadi efektif dan menyenangkan bagi anak- anak jika orang tua juga berpartisipasi dalam mendampingi anak-anak mereka di kelas.

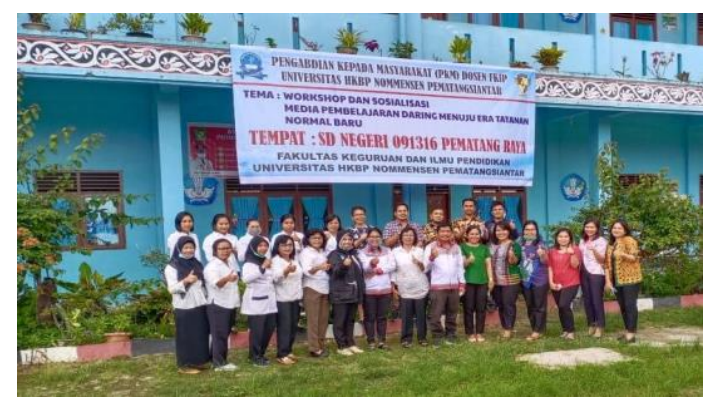

Gambar 3. Foto Bersama Kepala Sekolah dan Bapak/Ibu guru SD Negeri 091316

\section{SIMPULAN}

Guru memiliki fungsi yang penting agar anak dapat mengatur dan mengelola diri dalam memanfaatkan gawai dan koneksi internet. Guru memberikan tugas-tugas agar anak-anak dapat mengelola diri, memanfaatkan gawai dan internet untuk mendukung pembelajaran jarak jauh. Guru juga bertugas mengontrol aktivitas pembelajaran daring sekaligus memberikan masukan agar siswa terus memanfaatkan gawai, aplikasi, dan koneksi internet untuk mengembangkan pengetahuan. Orang tua perlu mendorong anak-anak agar dapat bertanggung jawab terhadap pemanfaatan gawai untuk hal-hal yang produktif. Kemampuan mengatur diri itu akan menjadi kecerdasan emosi anak untuk menghadapi era industri 4.0. Akhirnya, selalu ada hikmah dalam setiap peristiwa. Semoga pembelajaran daring bagi anak-anak membawa kebermanfaatan bagi masa depan mereka untuk menjadi sumber daya manusia (SDM) unggul Indonesia.

\section{UCAPAN TERIMA KASIH}

Ucapan terimakasih diberikan kepada bapak Kepala Sekolah SD Negeri 091316 Pematang Raya yang telah memberikan izin untuk melakukan pengabdian ini dan kepada Tim Pengabdian Dosen Universitas HKBP Nommensen Pematangsiantar yang telah berpartisipasi sehingga kegiatan ini dapat berlangsung dengan baik.

\section{DAFTAR PUSTAKA}

Ameli, A., Hasanah, U., Rahman, H., \& Putra, A. M. (2020). Analisis Keefektifan Pembelajaran Online Di Masa Pandemi COVID-19. Mahaguru: Jurnal Pendidikan Guru Sekolah Dasar, 2(1), 28-37.

Anhusadar, L. (2020). Persepsi Mahasiswa PIAUD Terhadap Kuliah Online Di Masa Pandemi Covid 19. KINDERGARTEN: Journal Of Islamic Early Childhood Education, 3(1), 44-58.

Anugrahana, A. (2020). Hambatan, Solusi Dan Harapan: Pembelajaran Daring Selama Masa Pandemi Covid-19 Oleh Guru Sekolah Dasar. Scholaria: Jurnal Pendidikan Dan Kebudayaan, 10(3), 282-289.

Atsani, K. H. L. G. M. Z. (2020). Transformasi Media Pembelajaran Pada Masa Pandemi COVID-19. Al-Hikmah: Jurnal Studi Islam, 1(1), 82-93.

Dewi, W. A. F. (2020). Dampak Covid-19 Terhadap Implementasi Pembelajaran Daring Di Sekolah Dasar. Edukatif: Jurnal Ilmu Pendidikan, 2(1), 55-61.

Fauzi, M. (2020). Strategi Pembelajaran Masa Pandemi Covid-19 Stit Al-Ibrohimy Bangkalan. AL-IBRAH, 5(2), 120-145.

Kebudayaan, M. P. D. A. N., \& Indonesia, R. (2020). Surat Edaran Nomor 4 Tahun 2020 Tentang Pelaksanaan Kebijakan Pendidikan Dalam Masa Darurat Penyebaran Coronavirus Disease (COVID-19).

Pamungkas, D. E., \& Sukarman, S. (2020). Transformasi Dunia Pendidikan Di Sekolah Dasar Dalam Masa Pandemi Covid-19. Jurnal Review Pendidikan Dasar: Jurnal Kajian Pendidikan Dan Hasil Penelitian, 6(3), 211-219.

Sanjaya, R. (2020). 21 Refleksi Pembelajaran Daring Di Masa Darurat. SCU Knowledge Media.

Siahaan, K. W. A., Manurung, H. M., \& Siahaan, M. M. (2021). Android-Based Learning Media Development Strategies During Pandemic Times To Improve Student Science Literature. International Journal of Education And Humanities, 1(1), 34-42. 
1216 Sosialisasi Penggunaan Aplikasi Youtube di SD Negeri 091316 Pematang Raya - Srinatalia Silaen DOI: https://doi.org/10.31004/abdidas.v2i5.452

Widyastuti, A. (2021). Optimalisasi Pembelajaran Jarak Jauh (PJJ), Daring Luring, Bdr. Elex Media Komputindo.

Windhiyana, E. (2020). Dampak Covid-19 Terhadap Kegiatan Pembelajaran Online Di Sebuah Perguruan Tinggi Kristen Di Indonesia. Perspektif Ilmu Pendidikan, 34(1), $1-8$.

Yusri, D., Dausat, J., Adnin, A. Y., \& Sahrul, S. (2020). Analisis Kemandirian Belajar Siswa Selama Pembelajaran Daring:(Studi Tentang Model Dan Penerapannya Di Mts Swasta Zakiyun Najah Sei Rampah). Jurnal Bilqolam Pendidikan Islam, 1(2), 1-18. 